\title{
A predominantly cervical form of spinal muscular atrophy
}

\author{
F Goutières, D Bogičevič, J Aicardi
}

Unité de Neurologie Infantile,

Département de

Pédiatrie et INSERM,

Hôpital des Enfants

Malades, Paris,

France

F Goutières

D Bogičevič

J Aicardi

Correspondence to: Dr Goutières,

Unité de Neurologie

Infantile,

Hôpital des Enfants

Malades,

149 rue de Sèvres,

75743 PARIS Cedex 15,

France

Received 6 February 1990

and in revised form

21 March 1990.

Accepted 20 June 1990

\begin{abstract}
Clinical heterogeneity within the group of spinal muscular atrophies (SMA) in children can pose practical problems of diagnosis, prognosis and genetic counselling. In addition to the classic forms, unusual cases have been described. Five children with an atypical type of SMA are reported, characterised by early involvement of cervical muscles contrasting with initially mild or absent affection of peripheral muscles. Secondary involvement of respiratory muscles was responsible for the death of three children in the second to fourth year. The disorder may be recessively inherited.
\end{abstract}

Spinal muscular atrophies (SMA) in children are a heterogeneous group of inherited disorders, characterised by widespread muscle weakness and atrophy secondary to degeneration of spinal motor neurons of unknown origin. On the basis of clinical and genetic criteria, different subgroups of SMA can be differentiated ${ }^{1-3}$ but there are still cases which are difficult to include in a particular group. ${ }^{45}$

We report five patients with an atypical form of SMA in which the neck muscles were initially and predominantly affected. This clinical presentation wrongly suggested the diagnosis of congenital myopathy. Two of these patients were brothers born to normal consanguineous parents.

\section{Case reports}

All the patients had a similar clinical presentation. To avoid repetition, only patient 1 will be fully described. The main clinical features of the children are shown in table 1 and the results of electromyography and muscles biopsies in table 2 . Information on patient 5 , the brother of patient 4 , was obtained from the parents and medical reports.

Patient 1 This was an eight month old boy referred because of poor head control which was first noticed by the parents when he was four months old. He was born at term, after a normal pregnancy and delivery. Birth weight was $3450 \mathrm{~g}$. Both parents were normal and unrelated. Intellectual development was normal but he could not hold up his head. At the age of eight months, he was hypotonic and lay in a frog-like position. He could sit supported but his head dangled because of pronounced weakness of both the anterior and posterior neck muscles. Tendon jerks were easily elicited in all four limbs; plantar reflexes were flexor. Tongue fasciculations were present. At the age of 16 months, he sat unsupported but had prominent weakness of the neck muscles so that the head could not be held erect and fell abruptly backward or forward depending on the position of its centre of gravity. Examination showed some intercostal muscle paresis but normal strength and motion in the four limbs. All tendon jerks were present. A plastic collar was installed to limit head dangling and

Table 1 Main clinical features

\begin{tabular}{|c|c|c|c|c|c|}
\hline Patient and sex & $1 M$ & $2 F$ & $3 M$ & $4 M$ & $5 M$ \\
\hline $\begin{array}{l}\text { Age at onset (months) } \\
\text { Age at first examination (months) } \\
\text { First clinical manifestation }\end{array}$ & $\begin{array}{l}4 \\
8 \\
\text { Poor head } \\
\text { control }\end{array}$ & $\begin{array}{l}6 \\
11 \\
\text { Poor head } \\
\text { control }\end{array}$ & $\begin{array}{l}4 \\
16 \\
\text { Poor head } \\
\text { control }\end{array}$ & $\begin{array}{l}3 \\
7 \\
\text { Poor head } \\
\text { control }\end{array}$ & $\begin{array}{l}3 \\
\text { Not examined } \\
\text { Poor head } \\
\text { control }\end{array}$ \\
\hline $\begin{array}{l}\text { Muscles atrophy and weakness } \\
\text { Neck } \\
\text { Arms proximal } \\
\quad \text { distal } \\
\text { Legs proximal } \\
\text { distal } \\
\text { Paravertebral } \\
\text { Intercostal } \\
\text { Tongue fasciculations }\end{array}$ & $\begin{array}{l}+++ \\
- \\
- \\
+ \\
\overline{+}+ \\
++ \\
\text { Present }\end{array}$ & $\begin{array}{l}+++ \\
+ \\
+ \\
+ \\
+ \\
++ \\
++ \\
\text { Absent }\end{array}$ & $\begin{array}{l}+++ \\
++ \\
- \\
- \\
\overline{+}+ \\
\overline{\text { Absent }}\end{array}$ & $\begin{array}{l}+++ \\
++ \\
+ \\
- \\
- \\
+ \\
++ \\
\text { Present }\end{array}$ & $\begin{array}{l}\text { Present very severe } \\
? \\
? \\
? \\
? \\
\text { Present } \\
\text { Present } \\
?\end{array}$ \\
\hline $\begin{array}{l}\text { Tendon jerks } \\
\text { Arms (age) }\end{array}$ & $\begin{array}{l}\text { Normal }(16 m) \\
\text { Absent }(25 m)\end{array}$ & Absent (11m) & Absent $(14 \mathrm{~m})$ & Absent $(7 \mathrm{~m})$ & $?$ \\
\hline Legs (age) & $\begin{array}{l}\text { Normal }(16 \mathrm{~m}) \\
\text { Absent }(25 \mathrm{~m})\end{array}$ & $\begin{array}{l}\text { Normal }(14 m) \\
\text { Absent }(20 \mathrm{~m})\end{array}$ & Absent $(14 \mathrm{~m})$ & Absent (7m) & $?$ \\
\hline $\begin{array}{l}\text { Evolution } \\
\text { Age at sitting unsupported } \\
\text { Age at walking with support } \\
\text { Age at walking unsupported }\end{array}$ & $\begin{array}{l}16 \mathrm{~m} \\
25 \mathrm{~m} \\
45 \mathrm{~m}\end{array}$ & $\begin{array}{l}6 \mathrm{~m} \\
\text { Not achieved } \\
\text { Not achieved }\end{array}$ & $\begin{array}{l}12 \mathrm{~m} \\
16 \mathrm{~m} \\
25 \mathrm{~m}\end{array}$ & $\begin{array}{l}\text { Not achieved } \\
\text { Not achieved } \\
\text { Not achieved }\end{array}$ & $\begin{array}{l}12 \mathrm{~m} \\
? \\
24 \mathrm{~m}\end{array}$ \\
\hline Follow up and outcome & 4y 6m Died & 25m Died & $39 \mathrm{~m}$ Alive & 7m Alive & 43m Died \\
\hline
\end{tabular}

+++ Very severe-completely paralytic; ++ Severe or $>1<3$ on the MRC scale; + Moderate or $\geqslant 3<4$ on the MRC scale; - normal or $\geqslant 4$ on the MRC scale. 
Table 2 Laboratory findings

\begin{tabular}{|c|c|c|c|c|c|c|c|}
\hline \multirow[b]{2}{*}{ Case } & \multirow{2}{*}{$\begin{array}{l}\text { Motor nerve } \\
\text { conduction velocity } \\
\text { (popliteal nerve) }\end{array}$} & \multicolumn{3}{|c|}{ Electromyogram } & \multicolumn{3}{|c|}{ Muscle biopsy } \\
\hline & & $\begin{array}{l}\text { Age } \\
\text { (months) }\end{array}$ & $\begin{array}{l}\text { Muscles } \\
\text { examined }\end{array}$ & Result & $\begin{array}{l}\text { Age } \\
\text { (months) }\end{array}$ & $\begin{array}{l}\text { Muscles } \\
\text { examined }\end{array}$ & Result \\
\hline 1 & $48 \mathrm{~ms}^{-1}$ & 17 & $\begin{array}{l}\text { Neck muscles, deltoid, } \\
\text { quadriceps femoris, } \\
\text { tibialis anterior }\end{array}$ & Neurogenic & 17 & Quadriceps femoris & $\begin{array}{l}\text { Neurogenic fascicular } \\
\text { atrophy }\end{array}$ \\
\hline 2 & $48 \mathrm{~ms}^{-1}$ & 11 & $\begin{array}{l}\text { Quadriceps femoris, } \\
\text { neck muscles, deltoid, } \\
\text { paravertebral muscles }\end{array}$ & $\begin{array}{l}\text { Normal } \\
\text { Neurogenic }\end{array}$ & $\begin{array}{l}11 \\
14\end{array}$ & $\begin{array}{l}\text { Quadriceps femoris } \\
\text { Deltoid }\end{array}$ & $\begin{array}{l}\text { Normal } \\
\text { Neurogenic fascicular } \\
\text { atrophy }\end{array}$ \\
\hline 3 & $38 \mathrm{~ms}^{-1}$ & $\begin{array}{r}7 \\
17\end{array}$ & $\begin{array}{l}\text { Neck muscles } \\
\text { Deltoid } \\
\text { Leg muscles }\end{array}$ & $\begin{array}{l}\text { "Myopathic" changes } \\
\text { Neurogenic } \\
\text { Normal or slightly } \\
\text { changed }\end{array}$ & $\begin{array}{r}7 \\
17\end{array}$ & $\begin{array}{l}\text { Quadriceps femoris } \\
\text { Deltoid }\end{array}$ & $\begin{array}{l}\text { Normal } \\
\text { Neurogenic fascicular } \\
\text { atrophy }\end{array}$ \\
\hline 4 & $40 \mathrm{~ms}^{-1}$ & 7 & $\begin{array}{l}\text { Neck muscles } \\
\text { Paravertebral muscles }\end{array}$ & Neurogenic & & Not done & \\
\hline 5 & Not done & & Not done & & & Not done & \\
\hline
\end{tabular}

prevent cervical cord trauma. At two years of age, the child could walk with support but his cry was weak and there was evidence of paradoxical respiratory movements with preserved diaphragmatic function, intercostal muscle paresis and marked chest deformity. Tendon jerks were then absent; all cranial nerve functions were normal. When he was three years old, he was still unable to walk alone, his neck muscles were extremely weak and atrophic and he had dorsal kyphosis and lumbar scoliosis but muscles of the scapular girdle and upper extremities were almost normal (4 on the MRC scale). Nine months later he started to walk alone and could ride a bicycle. Nevertheless, he had frequent respiratory infections and he died at the age of four years and six months from respiratory failure during measles. At the age of 17 months, the serum creatine kinase level was normal; motor nerve conduction velocity in the peroneal nerve was $48 \mathrm{~m} / \mathrm{s}$; electromyogram showed a neurogenic pattern in the posterior neck muscles group, quadriceps and deltoid muscles. Muscle biopsy from the quadriceps femoris (vastus lateralis) showed clusters of few small atrophic fibres typical of fascicular neurogenic atrophy.

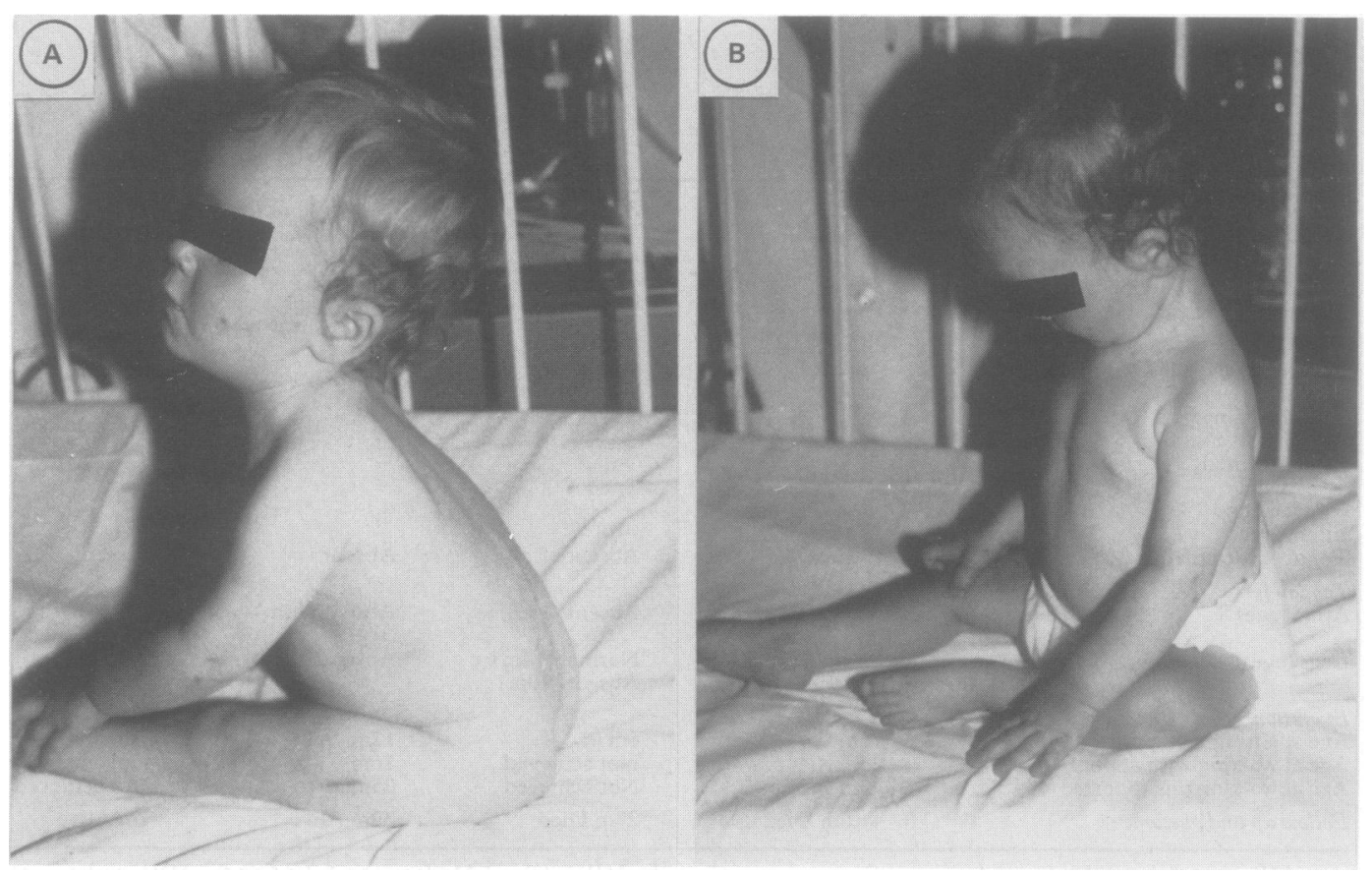

\section{Discussion}

The main clinical features and the initial presentation of the five patients include severe weakness and atrophy of the neck muscles during the first six months of life. As a result, the head dangles and falls abruptly downward or backward depending on the position of its centre of gravity (fig a and b). In contrast with this severe paralysis of the neck muscles, there is, at onset, only mild involvement of the limbs, mainly the upper limbs, and almost normal strength in the lower limb muscles. Within a few months, the paralysis proceeds caudally and, after one to two years the lower limbs are Three children, however, achieved independent walking at 24, 25 and 45 months. Respiratory muscles become involved and paralysis of the intercostal muscles results in thoracic deformity and is the major complication of this disorder leading to death from respiratory insufficiency in three children.

Paravertebral muscles are also severely affected with early dorsal kyphosis and lordosis which may aggravate respiratory insufficiency. Bulbar involvement may occur as shown by the presence of tongue fasciculations. Deep tendon also affected, mainly in their proximal part.
Figure Patient 2 at 11 months of age. She is able to sit unsupported but with the head falling backward (a) or forward (b) according to the position of its centre of gravity. 
reflexes may be initially preserved. All the children have a normal intelligence and none has abnormal sensorium, bladder dysfunction or pyramidal tract signs. Electromyographic studies show signs of denervation with high amplitude polyphasic potentials and normal motor nerve conduction velocities. These alterations predominate in the cervical, paravertebral and shoulder muscles and may be absent in muscles of the lower limbs. In one case, an early EMG was reported as "myogenic" but was later found to show a neurogenic pattern in more severely affected muscles. Muscle biopsy shows groups of small atrophic fibres suggestive of neurogenic fascicular atrophy in the shoulder girdle muscles but may be normal in the lower limbs. In two patients it was necessary to repeat the biopsy on the deltoid.

Although the clinical presentation with extreme neck muscles weakness and atrophy may at first suggest myopathic disorder, the presence of tongue fasciculations in two patients, the results of the electrophysiological studies and of the muscle biopsies are diagnostic of an anterior horn cell disease. The disease, however, seems different from all the varieties of SMA reported so far. It differs from the early infantile form of SMA type I or WerdnigHoffman (W-H) disease ${ }^{1-3}$ because of its more protracted course as children with $\mathrm{W}-\mathrm{H}$ rarely survive the first year of age, also because of the achievement of independent walking which is never observed in SMA type I, and because of the less severe respiratory paralysis with later onset. In W-H disease, severe involvement of the neck muscles may occasionally be seen ${ }^{6}$ but no case has been recorded in which severe weakness and atrophy of the neck muscles constituted the main and only initial problem.

The cases we report are also different from the chronic childhood SMA type II, ${ }^{6}$ intermediate form ${ }^{2}$ or arrested Werdnig-Hoffman disease ${ }^{7}$ which usually begins around the age of six months with weakness predominating in the proximal muscles of the lower limbs and runs a more benign course with survival into adolescence or adulthood. Although occasionally, this type of chronic generalised spinal muscular atrophy may have an onset as early as three months, ${ }^{7}$ none of the patients of Pearn and Wilson was ever able to crawl normally, pullto-stand or walk which distinguishes them from our cases; three of our patients were able to walk and four to sit unsupported which less than $25 \%$ of patients with arrested WerdnigHoffman disease can do. ${ }^{7}$ The downward progression of the paralysis from upper to lower limbs in our children is another distinctive feature from SMA type II which always predominates in the lower limbs.
The more chronic SMA type III or Kugelberg-Welander syndrome which starts after onset of walking and runs a relatively mild course with proximal limb muscle weakness is clearly a distinct disorder.

Our cases are also different from other cases of atypical infantile SMA presenting with neonatal respiratory distress and early diaphragmatic paralysis ${ }^{4}$ or with encephalopathy and olivopontocerebellar atrophy.

Bulbar involvement in two of our patients with tongue fasciculations may suggest a relation between the present cases and FazioLonde disease. ${ }^{8}$ However, none of our patients had multiple cranial nerve palsies which are the main features of this condition.

The remarkable similarity of the clinical features of the five patients presented and the occurrence of the disease with identical characteristics in two brothers born to consanguineous parents suggest that this disorder represents a distinct subgroup within the group of SMA, and may have an autosomal recessive transmission.

Although we were not able to find similar cases in the literature we are aware of two patients with the same clinical presentation and fatal outcome (Z Sfaello, V Dubowitz, personal communications). The patient of V Dubowitz was initially reported as "unspecific congenital myopathy with minimal change myopathy", but was later recognised as having spinal muscular atrophy with predominant cervical muscle paresis.

The diagnosis of this type of infantile SMA may initially raise problems because of the localised involvement and consequent negativity of standard examinations. Recognition is important, however, because of the probable genetic implications.

1 Pearn J. Classification of spinal muscular atrophies. Lancet 1980;1:919-22.

2 Dubowitz V. Spinal muscular atrophies In: The floppy infant. Clinics in developmental medicine 76 . London: Spastics International Medical Publications, 1980:20-31.

3 Hausmanowa-Petrusewicz I, Fidzianska-Dolot A. Clinical features of infantile and juvenile spinal muscular atrophy. In: Gamstorp I, Sarnat HB, eds. Progressive spinal muscular atrophies. New York: Raven Press, 1984:31-42.

4 Mellins RB, Hays AP, Gold AP, Berdon WE, Bowdler JD. Respiratory distress as the initial manifestation of Werdnig-Hoffmann disease. Pediatrics 1974;53:33-40.

5 Goutières F, Aicardi J, Farkas A. Anterior horn cell disease associated with ponto-cerebellar hypoplasia in infants. J Neurol Neurosurg Psychiatry 1977;40:370-8.

6 Gamstorp I. Progressive spinal muscular atrophy with onset in infancy or early childhood. Acta Paediatr Scand 1967;56:408-23.

7 Pearn JH, Wilson J. Chronic generalized spinal muscular atrophy of infancy and childhood. Arrested WerdnigHoffman disease. Arch Dis Childh 1973;48:768-74.

8 Gomez HR, Clermont V, Bernstein J. Progressive bulbar paralysis in childhood (Fazio-Londe's disease). Arch Neurol 1962;6:317-23.

9 Dubowitz V. Muscle disorders in childhood. Major problems in clinical pediatrics. Vol. XVI. London: NB Saunder Company, 1978:105-6. 